\title{
A good sheep station ruined
}

\author{
JAMES MCDONALD
}

The quip that Canberra is 'a good sheep station ruined' has been repeated since at least the early 1960s. But it may have entered the local vernacular decades earlier; perhaps coined by an old farmer annoyed by the burgeoning beige of the young city's concrete brutalism. These days, the jibe lives on as part of the smorgasbord of wit indulged by an ever-lengthening queue of Canberra bashers. ${ }^{1}$ If the capital is not being criticised as a blight on the landscape or the source of the nation's political woes, it is bagged for its sleepy ways by detractors too hip for a quieter pace. What is certain is that Canberra will never win itself a popular image as long it remains the seat of government. It may or may not be true to say that our politicians and administrations since 1913 have disappointed us and, therefore, 'ruined' this good sheep paddock, but the first part of the aphorism is certainly fact. Indeed, the Limestone Plains had world-class sheep stations. At times its fleeces secured worldrecord prices.

Post-invasion, the pastoralists and agricultural workers on the Limestone Plains consistently over-achieved. ${ }^{2}$ At Booroomba, near Tharwa, William Davis senior set up innovative boiling down works for tallow manufacture to make ends meet during a downturn in the late 1840s. At the same time, his son (William Davis junior) turned Ginninderra estate into a model farm, admired throughout the colony. In the early 1860 s some local wheat growers were getting in excess of 60 bushels to the acre. Later, William Farrer famously developed his robust droughtand rust-resistant high-yielding strain of wheat at Lambrigg station. The Smiths and McCarthys at Hall, and the Campbells at Duntroon bred some of the best working horses in the country. In 1873 the local blacksmith, Flourence McAuliffe, was adapting the latest Scottish methods to forge prize-winning ploughs. A few decades later, the Gribbles at Gungahlin ensured that the Limestone Plains was one of the first districts to access new steam technology for threshing and chaffcutting operations. At 'Hazlebrook', Oaks Estate, during the early 1880s the Bull brothers set up a wool-washing and fellmongering works, which was later operated by George Tompsitt. In the 1890s fine Angus and Devon herds were bred in the region. In the same decade, the district's orchardists were so successful that they were

\footnotetext{
1 The earliest written reference I can find to the quip is in the Canberra Times, 7 November 1967, 18.

2 Not to mention, of course, the ancient history of land management in the region preceding the British invasion. See Bill Gammage, The Biggest Estate on Earth: How Aborigines Made Australia (Crows Nest, NSW: Allen \& Unwin, 2011).
} 
exporting bins of apples to London, long before Batlow emerged as the dominant apple area in south-western New South Wales. This was all achieved despite record floods, drought and the economic depression of the 1890s.

Into the first years of the new century, the Majura wheelwright Walter McIntosh was manufacturing his own wool presses. In 1905 the farmers at Ginninderra set up an early farmers' union, well ahead of its time. ${ }^{3}$ And then, after the formation of the Federal Capital Territory (FCT; Australian Capital Territory (ACT) from 1938), there is the impressive record of the Commonwealth Scientific and Industrial Research Organisation, which had experimental paddocks where many of Canberra's northern suburbs now sprawl. ${ }^{4}$ Well before King O'Malley, the Minister for Home Affairs, drove in the first survey peg for the city in February 1913, the Limestone Plains district had established itself as an important agricultural district. But, as we will see, in the field of fine wool production, the region excelled. It produced some of the best clips of the postwar wool boom, snapped up by international buyers from the Milanese fashion houses and the costume departments of the Muscovite theatres.

\section{Grazing before the FCT}

Before the Territory was established in 1913, European occupation and farming had followed a similar pattern to other areas in south-western New South Wales (NSW). Absentee 'squires' had been quick to monopolise river frontages and grassland plains. They despatched overseers and convict teams with small flocks and herds to establish

3 For the boiling down works, see Bruce Moore, Cotter Country: A History of the Early Settlers, Pastoral Holdings and Events in and around the County of Cowley, NSW (Lyneham, ACT: Greg Moore, 1999), 70. For the early wheat growers and high yields, see Samuel Shumack, An Autobiography, or Tales and Legends of Canberra Pioneers, ed. J. E. and Samuel Shumack (Canberra: Australian National University Press, 1967), 48, 111, 114, 155-57, 161-62; Lyall Gillespie, Canberra: 1820-1913 (Canberra: AGPS Press, 1991), 162, 259-66. The literature for Farrer is voluminous, but see Archer Russell, William James Farrer, a Biography (Melbourne, Vic.: Cheshire, 1949); the entry in the $A D B, C$. W. Wrigley, 'Farrer, William James (1845-1906)', Australian Dictionary of Biography, National Centre of Biography, The Australian National University (hereafter $A D B$ ), adb.anu.edu.au/biography/ farrer-william-james-6145; and Errol Lea-Scarlett, Queanbeyan: District and People, (Queanbeyan, NSW: Queanbeyan Municipal Council, 1968), 68. For horse breeding, see Gillespie, Canberra: 1820-1913, 148-49, 160; Leon R. Smith, Memories of Hall (Canberra: Roebuck Society 1975), 18. For McAuliffe and Wilson, see Shumack, An Autobiography, 76; James McDonald, Three Henry Currans (Canberra: Sorley Boy, 2018), 289-304. For the Gribbles' traction engine, see Smith, Memories of Hall, 49, 53, 77, 90-92; Lyall L. Gillespie, Ginninderra, Forerunner to Canberra: A History of the Ginninderra District (Campbell, ACT: L. L. Gillespie, 1992), 95-96, 101-2, 222; Dorothy Mulholland, Far Away Days: A History of the Murrumbateman, Jeir and Nanima Districts (Murrumbateman, NSW: Murrumbateman Old School Grounds Committee, 1995), 199-201; James McDonald, 'The Chaff Cutters: the Gribbles of Ginninderra', Canberra Historical Journal 79 (2017): 11-19. For the Oaks Estate tannery, see Karen Williams, Oaks Estate: No Man's Land (Canberra: K. Williams, 1997), 150-51. Thanks are due to Gillian Kelly for alerting me to this. For beef cattle, the Ginninderra Farmers' Union, McIntosh's wool presses, and early apple production, see Gillespie, Canberra: 1820-1913, 195-96, 202, 257; Gillespie, Ginninderra, 155-58.

4 See Brad Collis, Fields of Discovery: Australia's CSIRO (Crows Nest, NSW: Allen \& Unwin, 2002), 103, 107-92, 221-29. 
remote farms. Some of the main stations set up in this manner in the late 1820 s were Moore's Canberry (near Acton), Campbell's Pialligo (later called Duntroon), John Palmer's Jerrabomberra, George Palmer's Ginninderra (then spelt 'Gininderra', but now known now as Gold Creek), and the grants of Donnison and Klensendorlffe at Yarralumla. ${ }^{5}$ Murdoch's Tuggeranong and MacPherson's Springbank (the remnant, now an island in Lake Burley Griffin) followed soon after in the 1830 s. $^{6}$

From the outset, it looked like the Limestone Plains district was destined to be prime sheep country. Early flocks were sourced from stock selected from Macarthur's pens. By the late 1830s the two biggest stations, Duntroon and Yarralumla, were running about 25,000 head each, which made them some of the largest sheep stations in the colony. ${ }^{7}$ But it was not just the quantity that was of note; the quality of Canberra wool quickly became apparent. In 1869 Andrew Cunningham at Lanyon took out the fine wool prize at the NSW agricultural show for his Negretti rams. ${ }^{8}$

With no fences, these early spreads required large workforces of shepherds, haystackers, bullockies, drovers, cooks, gardeners, carpenters, blacksmiths, wheelwrights and general farm labourers. They recruited convicts and a trickle of bounty migrants and emancipists ('lags'), many of whom later established their own small farms on poorer ground or as tenants within the larger stations. At Ginninderra, William Davis junior employed Ngunnawal drovers. ${ }^{9}$ But in the early 1860 s came a flood of free selectors, largely as a result of Robertson's land reforms. ${ }^{10}$ One local selector, Samuel Shumack, who witnessed this dramatic change at his own family's 100-acre selection at Weetangerra, described the resentment of the large landholders.

William Davis - who was father's employer and the squatter on whose land we selected-has 20,000 acres, excluding some thousands of acres of Crown land for which he paid very little, yet he resented our efforts to strike out for ourselves and laughed at what he derisively called 'Shumack's Folly'.

'Three years', he said, 'will see Shumack and his family sadder and wiser, for shortage of water will drive them out.' His prophecy miscarried! ${ }^{11}$

5 For the first four of these pastoralists, see the articles in the $A D B$ at: L. F. Fitzhardinge, 'Moore, Joshua John (1790-1864)', $A D B$, adb.anu.edu.au/biography/moore-joshua-john-2475; Margaret Steven, 'Campbell, Robert (1769-1846)', $A D B$, adb.anu.edu.au/biography/campbell-robert-1876; Margaret Steven, 'Palmer, John (1760-1833)', $A D B$, adb.anu.edu.au/biography/palmer-john-2533; Margaret Steven, 'Palmer, George Thomas (1784-1854)', $A D B$, adb.anu.edu.au/biography/palmer-george-thomas-2532.

6 Generally, see David Meyers, Lairds, Lags and Larrikins: An Early History of the Limestone Plains, ed. Kevin Frawley (Pearce, ACT: Sefton, 2010), 14-37; Nicholas Brown, A History of Canberra (Melbourne: Cambridge University Press, 2014), 6-36.

7 Gillespie, Canberra: 1820-1913, 29-30.

8 Gillespie, Canberra: 1820-1913, 147-48.

9 Lyall L. Gillespie, Aborigines of the Canberra Region (Campbell, ACT: L. L. Gillespie, 1984), 34-35, 56-61; Gillespie, Ginninderra, 36-40.

10 See Bede Nairn, 'Robertson, Sir John (1816-1891)', $A D B$, adb.anu.edu.au/biography/robertson-sir-john-4490. 11 See Shumack, An Autobiography, 46. The Shumack homestead, Springvale, stood where the Cameron Offices in the Belconnen Town Centre are now located. 
Like the Shumacks, many of Canberra's free selectors became successful farmers. By the first decade of the twentieth century, the Limestone Plains was a mix of larger stations (the remnants of the original runs) and smaller but emerging properties. The grip of the squatters had been loosened. Over these years there was also less reliance on grain farming (perhaps due to the low and erratic seasonal rains) and an increasing investment in livestock.

In the 1906-13 period, pastoral life in the district was again forced to reorganise. Speculation was mounting that the new Federation's national capital would be situated close to Queanbeyan, if not at the township itself. Eventually, the authorities announced the location and the resumption of hundreds of properties and part blocks to form its new FCT. ${ }^{12}$ Survey work began in earnest in 1911, although political decision-making lingered. Land developers anticipated a windfall, while farming families feared ruin. Only about 12 per cent of the 912 square miles of the soon-to-be-FCT was Crown land. There were around 220 freehold landowners farming in the district. Resumptions began in earnest in 1913 and compensation was paid at amounts significantly below the true value of the land. ${ }^{13}$ In those days there was certainly the view that good Canberra sheep stations were being ruined.

Some of the larger families tried fighting the acquisition, but invariably lost. The few who took the government to court had costs awarded against them, which meant that they lost even their compensation money. The locals formed a Vigilance Committee through which, collectively and respectfully, they had hoped to consult with the Commonwealth Government, but the administration had no appetite for genuine dialogue. King O'Malley reacted bitterly to the efforts of the landowners for proper compensation. Many old families left the district in disgust, not being able to abide the thought of remaining as tenants on land they had once owned. ${ }^{14}$ Others had more serious disputes to resolve, particularly farmers whose properties straddled the border. The arbitrary cartographic division meant that, in some cases, properties were partitioned in such a way that at least one of their new blocks became unviable as a separate farm. Some of these, such as Edmund Rolfe at Gold Creek, continued the fight and were eventually compensated more adequately. ${ }^{15}$

12 This is a story eloquently conveyed by B. Maher and G. Wood in 'Title Fights: Jeremiah Keeffe and the Federal Capital Territory Vigilance Association', Canberra History Journal 62 (2009): 19-24. Also see Frank Brennan, Canberra in Crisis: A History of Land Tenure and Leasehold Administration (Canberra: Dalton, 1971), 18-56; and Matthew Higgins, 'Surveyors at the Snowline: Surveying the ACT-NSW Border, 1910-15', Canberra History Journal 47 (2001): 2-8.

13 Maher and Wood, 'Title Fights', 20-21.

14 For example, the Harcourts and Craces at Ginninderra, and the Keeffes at Guises Flat.

15 Specifically, Rolfe's 3,940-acre Gold Creek station was resumed in 1915 for $£ 13,500$. 


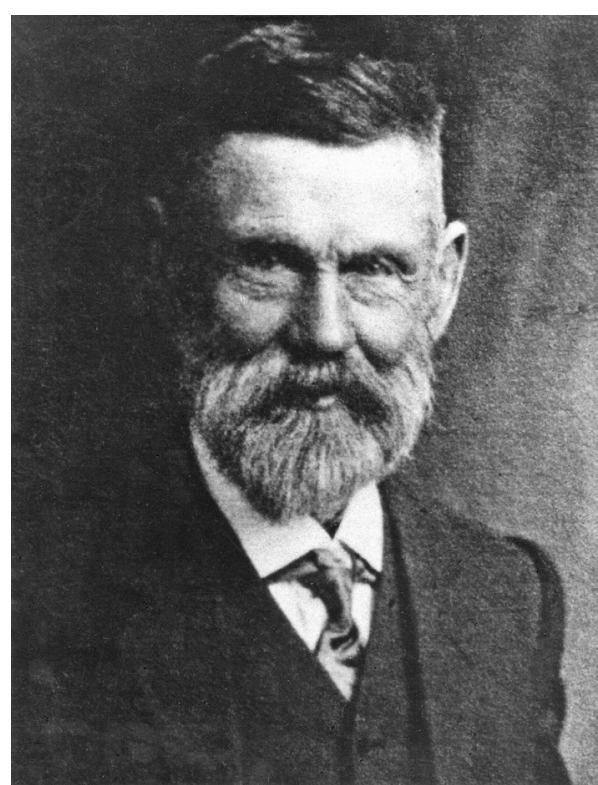

Figure 1: Edmund Rolfe of Gold Creek. Source: Author's collection.

An unexpected effect of these land resumptions was that wool production actually increased in the decades after 1913. This seems to have occurred because the bigger pastoralists left and the balance shifted in favour of the smaller farmers who found sheep rather than cattle more 'affordable' to run. Flocks displaced some herds. The sheep stock of the FCT more than doubled from 1922 to $1932 .{ }^{16}$ Of course, as the suburbs grew-particularly from the population influx of the early 1960sthe farmers diminished in number and their sheep flocks with them.
Despite the cadastral carnage, there were unique opportunities. The changes meant that, if farmers were willing to take the risk of leasing cheap properties affected by the acquisition, they could either establish a new farm or expand an existing holding, albeit in the knowledge that, in a generation or two, suburbs would eventually swallow up your hard work. On the NSW side of the border, farmers could purchase portions of split properties from disgruntled border farmers willing to sell them off cheaply, or they could lease these parcels from the land speculators who had swooped to purchase as much as they could in the wake of the bureaucratic destruction of $1913-15 .{ }^{17}$ On the FCT side, the government was keen to arrange cheap leases on abandoned properties and a number of local entrepreneurs purchased them, particularly those with contiguous blocks. There was even a very solid allegation of corruption debated in parliament. David Miller, King O'Malley's departmental secretary, was one of the two key administrators of the land resumptions. His son, Selwyn Miller, was said to have fraudulently benefited from the bidding process for bundled leases. ${ }^{18}$

16 In 1922 the combined FCT sheep flock was reported as 105,379; in 1932 it had grown to 280,859. Canberra Times, 28 September 1933, 2.

17 For example, the speculative purchases of H. F. Halloran, for whom, see John Atchison, 'Halloran, Henry Ferdinand (1869-1953)', $A D B$, .

18 See Maher and Wood, 'Title Fights', 23. 


\section{Canberra graziers before the wool boom}

When the 1913 dust had settled, there were a number of pastoralists operating successfully on the fringes of the national capital. The 28 September 1933 edition of the Canberra Times published a summary of the best wool-growers in the FCT, showing a mix of seven growers, some established and some emerging. These were:

- Glenwood station, the estate of the recently deceased James Vincent Hibberson who had invested heavily over the years in stud rams. ${ }^{19}$

- A number of holdings run by different members of the ubiquitous Southwell family in the northern reaches of the FCT who had built their bloodlines on Merriman stock; particularly Lindsay Edwin Southwell at Fairview. ${ }^{20}$

- The Kilby Brothers at Hall who based their flock on Starr and Son's rams from Dalton. ${ }^{21}$ From this pioneering family there was also James Kinloch Kilby of Parkwood who was described as one of 'the oldest breeders in the district'. ${ }^{22}$

- Harry Vest of Weetangerra, a small grazier producing some of the finest quality fleeces that had also been based on Merriman bloodlines. ${ }^{23}$

- The Moore brothers of Hall, known for their sturdy flock of large-framed sheep with heavier fleeces. ${ }^{24}$

- The well-established station of Frank Snow at Cuppacumbalong, where he ran a large flock on rolling pasture..$^{25}$

- The emerging Deasland stud of Henry 'Babe' Curran at Ginninderra who had also invested in Merriman stock and was showing much potential as the youngest of these graziers in 1933 .

19 For Hibberson, see Smith, Memories of Hall, 18; Gillespie, Ginninderra, 70, 90, 94, 159, 225; Chris Newman, Gold Creek: Reflections of Canberra's Rural Heritage (Canberra: Gold Creek Homestead Working Group, 2004), 28.

20 The Southwells were one of the most numerous families in the district. See L. L. Gillespie, The Southwell Family: Pioneers of the Canberra District, 1838-1988 (Canberra: Southwell Reunion Committee, 1988); and the interviews of Una West and June Southwell by Bert Sheedy in 1974 (National Library of Australia (NLA) recording Bib. ID 5151247) and Jean Southwell by Matthew Higgins on 16 September 1991 (NLA recording Bib. ID 1400847). For Lindsay Southwell, see Gillespie, Ginninderra, 80, 185, 241-42.

21 The Kilbys were a prominent family from the Hall district. The three brothers, who operated at the Falls under the partnership known simply as Kilby Brothers, were Clyde, Bruce and Cleon. See Smith, Memories of Hall, 66; Gillespie, Ginninderra, 228-29.

22 For James Kilby, see Smith, Memories of Hall, 16-17; Gillespie, Ginninderra, 161-66.

23 The obituary of his father, Richard Vest (Queanbeyan Age, 24 November 1922, 6) tells us that he came to Australia from England as a young man and established himself working for the Campbells at Duntroon, and then at Yarralumla, where he married Christina Kilby. Cf. Margaret Clough, Spilt Milk: A History of Weetangera School, 1875-2004 (Canberra: Weetangera School, 2004), 44.

24 In particular, James Courteney Moore of Gledeswood was a leading farmer and elder of the Anglican community (Smith, Memories of Hall, 22; Gillespie, Ginninderra, 165, 185-86, 234; and Neil Manton, St Michael and All Angels: The History of a Village Church (Charnwood, ACT: Parish of St Barnabas, 1999), 5, 15, 23).

25 Snow hosted Elizabeth II when she stayed at Cuppacumbalong during the royal visit in 1954. See Moore, Cotter Country, 117. 


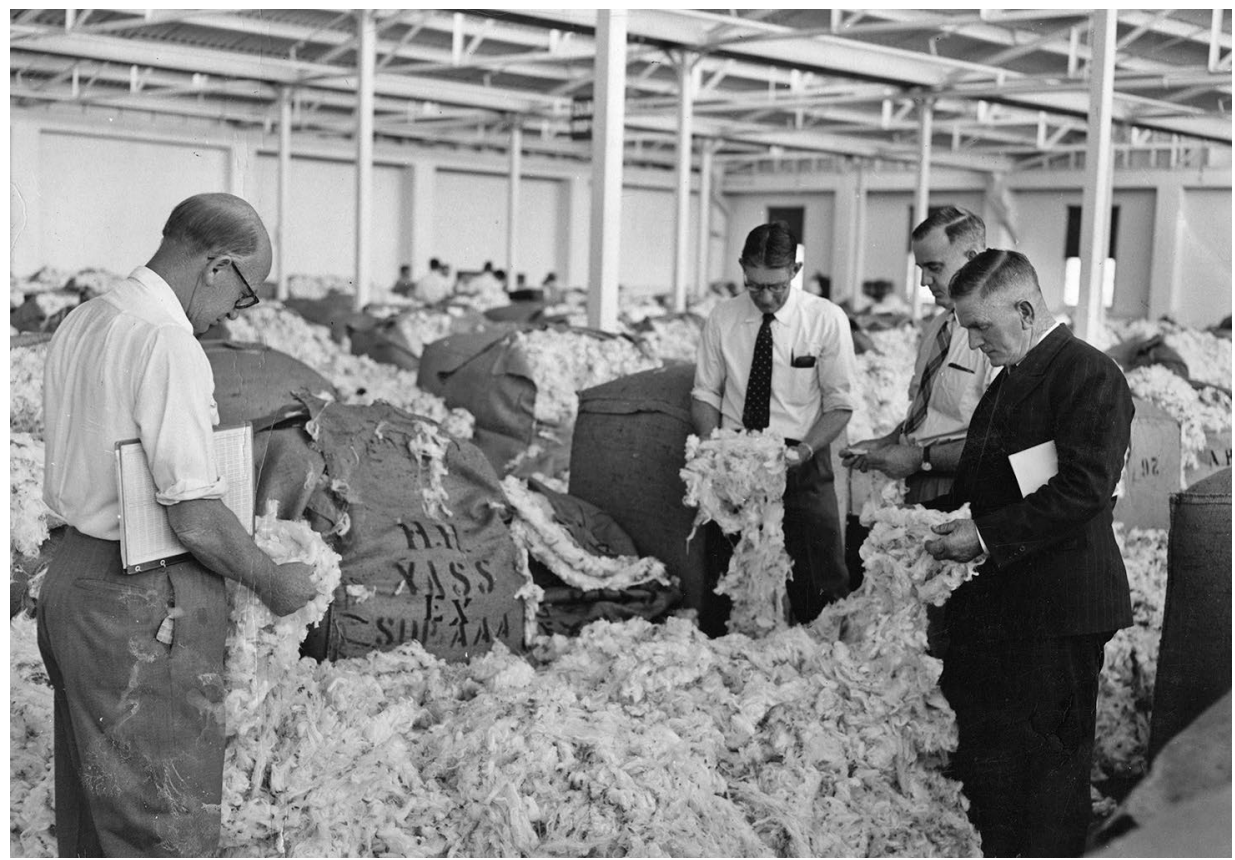

Figure 2: Goulburn Wool Sales, 1957: assessment of the Deasland Clip (HH Yass Brand), which had just achieved two world-record prices. Babe Curran is the man in the dark suit at the right.

Source: Author's collection.

The article also mentioned a number of breeders on properties over the border who exhibited at the FCT Shows. ${ }^{26}$ Babe Curran's property at Ginninderra, perhaps the most successful of these FCT/ACT graziers during the postwar wool boom, provides a good case study of the experience of Limestone pastoralists as Canberra grew. His case in many ways is atypical in that he was self-made and had to build up his flock and landholdings from scratch, but Curran became the best among them and the largest wool producer of the FCT/ACT. The Deasland clip of Ginninderra illustrates how good the Canberra pasture could be. ${ }^{27}$

26 Another article (Canberra Times, 31 March 1943, 3) lists 12 leading graziers of each FCT district as a potential donor for a wartime fund-raiser. The men are: F. S. Southwell (probably Fred) for Ainslie, Athol C. Kilby for Hall, Ernie Cavanagh for Mulligan’s Flat, Henry 'Babe' Curran for Ginninderra, R. Cameron (probably Rupert) for Weetangerra, Philip H. Champion for Kambah, Frank Snow for Cuppacumbalong, F. J. McCormack ('F. J.' is a misprint for 'T. J.' [= Timothy J.]) for Tuggeranong, Rockley Buckmaster for Uriarra, David Watt Cargill for Fyshwick, D. Cameron (probably Donald junior) for Duntroon, and R. Read (probably Robert 'Bert') for Jerrabomberra. Four of these 12 men share surnames with the seven families of the 1933 article.

27 For Curran's career and dominance of the wool sales from 1944 to 1964, see James McDonald, 'When Ginninderra Grew the Golden Fleece', Canberra History Journal 75 (2015): 15-23. 


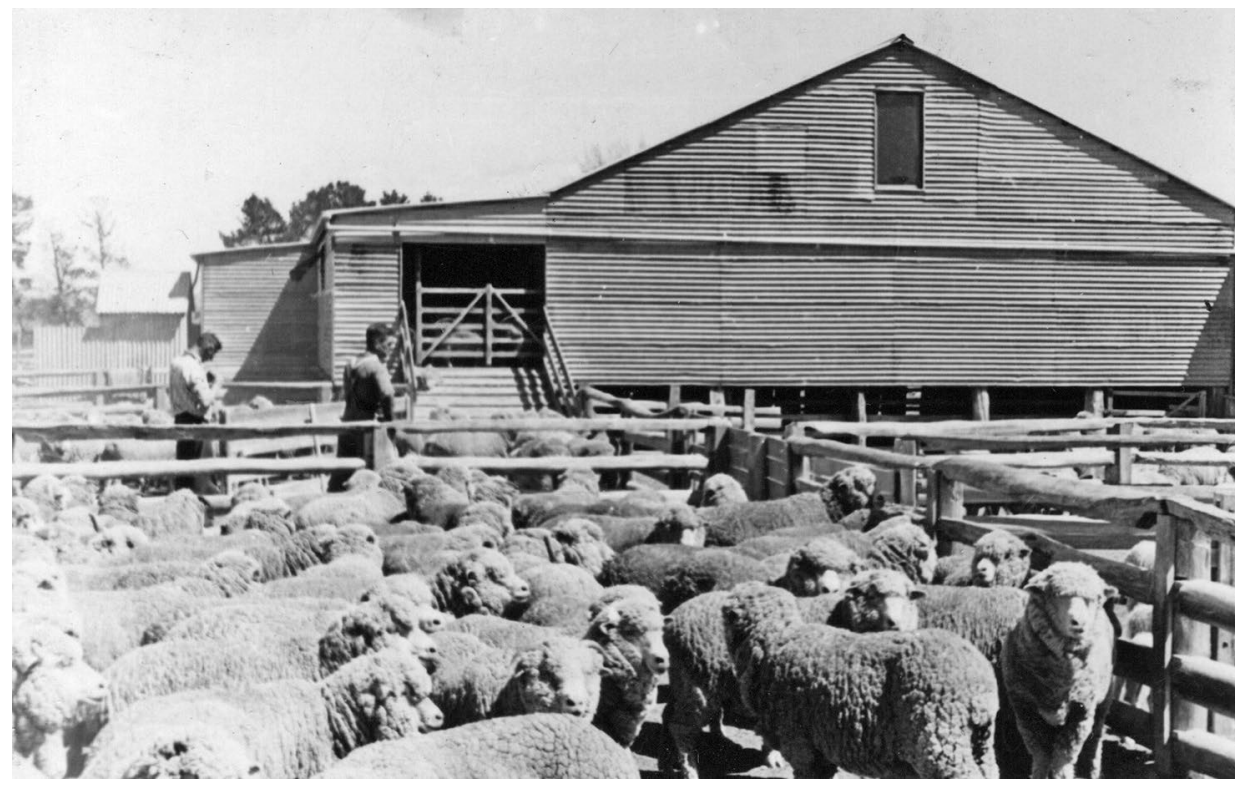

Figure 3: L-R: Noel Burton (leading hand) and Babe Curran in the mustering yards outside the Deasland shearing shed, 1940.

Source: Author's collection.

Curran was one of those who took advantage of the changes of 1913, methodically building up a mix of over 14,000 acres (much of it in the ACT) on which he ran a flock of over 10,000 of Australia's finest merino sheep. Without an inherited farm or head start, in a sense, he had no choice but to look to the opportunity of the land resumptions. His mother, Agnes Gribble, was from a local family who had dominated the district's threshing, chaff-cutting and hay-stacking market since 1861. His father, Henry Roland Curran (known as 'Harry'), had been orphaned when young and had spent his working life at a blacksmith's forge, and indeed was the last full-time blacksmith of the ACT. ${ }^{28}$ Babe's older brother, Arthur 'Chappie' Curran, ran what little land the family had; largely near the Ginninderra smithy, taking in Percival Hill. Babe Curran's first paid work was as a roustabout at Gungahlin station. ${ }^{29}$

In 1921 Curran married Amy Reid. At first, they lived in one of the deserted Palmerville cottages near the old convict barracks in the vicinity of the now suburban Giralang. By 1927 they had saved enough to buy the lease for Deasland, a rundown 1,200-acre property and homestead built for the Harcourt family in $1893 .{ }^{30}$

28 For Harry Curran, see McDonald, Three Henry Currans, 91-110.

29 Obituary in The Queanbeyan Age, 15 October 1964, 4.

30 Deasland was built in 1893 by George Harcourt. See Gillespie, Ginninderra, xxi, 41, 104-5, 175-77, 182-86; G. Barrow, Canberra's Historic Houses: Dwellings and Ruins of the 19th Century (Canberra: Dagraja Press, 1998), 12-13. Since the Harcourts walked away after the 1913 land resumption, the property had had three short-term lessees as well as one manager and had been in serious decline. 
The Currans repaired the fences, improved the pasture with superphosphate and better land management and borrowed heavily to assemble quickly the infrastructure necessary for them to create a functional sheep station. By the 1950s, Curran was leasing or purchasing blocks at Ginninderra, Gungahlin, Mulligans Flat, Wallaroo, Murrumbateman, Tallagandra and Wee Jasper. Through hard work and business nous, he transformed this patchwork of paddocks into some of the best superfine wool-producing pasture in the nation. In his later years, Curran said that he was very deliberate in not consolidating a single holding. He explained the strategy by saying that in this way he could never be burnt out. As a seven-year-old, he had witnessed the devastating bushfires of 1905, in which many properties and homes in Ginninderra village were destroyed. ${ }^{31}$ It had also been a cheap way of accumulating enough pasture to maintain a large flock.

Curran saved everything he earned and slowly built up a flock, agisting wherever he could and grazing on common land and on roadsides and stock routes ('the long paddock'). He seems to have started his own bloodline with a pen or two purchased from the Crace family at Gungahlin, or from his father-in-law, Richard Reid, a small (but successful) grazier at nearby Tallagandra. ${ }^{32}$ Given the piecemeal nature of the sources, there is not a comprehensive picture of how Curran built up his bloodline, but enough basic information has survived to show that, at first, he was frugal, but later made some ambitious stud investments. A newspaper report says that he bought a mob of 'expired' Merryville ewes in 1919, Sir Walter Merriman's sheep stud near Yass. ${ }^{33}$ Expired ewes were old sheep with only one or two lambing seasons, at best, left in them. It was not until the 1930s that Curran could afford to buy stock at prime age. In 1936 he bought a single ram for 35 guineas (about $\$ 4,500$ in modern value). ${ }^{34}$ The accounts covering the war seasons for Curran's Deasland clip have survived. In them we can see a significant investment in bloodlines during the period. His stud purchases at this time represented 23 per cent of the total Deasland clip expenditure for the war years, about $\$ 280,000$ in modern value.

It took the Currans about 25 years to get everything in place, but the records soon flowed for the 'HH Yass brand' clip run out of the old Deasland shearing shed where the roundabouts of Nicholls now circle. Curran briefly held the top price for merino wool under the wartime appraisement scheme; the period when government regulators controlled markets over the five wool seasons between 1940 and $1944 .{ }^{35}$

\footnotetext{
31 Gillespie, Ginninderra, 141-42.

32 For the Craces, see C. Coulthard-Clark, 'Gungahlin Revisited', Canberra History Journal 26 (1990): $26-34$. For the Reids, see Lyall L. Gillespie, A Pictorial History of the Read/Reid Family in Australia, 1849-1979 (Canberra: L. L. Gillespie, 1979).

33 For which, see David Moeller, The Merryville Type: How Excellence Bred Brilliance (Copacabana, NSW: Lexington Avenue Press, 2001).

34 According to the Reserve Bank of Australia’s 'Pre-decimal Inflation Calculator'. The other estimates of current value provided in this paper are also derived using this tool.

35 Canberra Times, 28 October 1944, 2.
} 
He topped the Goulburn or Sydney wool sales on at least 19 occasions, set the NSW record in eight seasons, and achieved the highest national and Commonwealth prices for a season six times. In the postwar period, with the return to an open market, top wool prices for the best bales of Australian superfine wool increased almost 11-fold. It is reported that in 1945 Curran set a world-record price. At this sale, two Italian fashion mills competed for his clip. ${ }^{36}$ It is also said that he became the first wool-grower to get over $£ 1$ for 1 lb of wool (i.e. a 'pound for a pound') and $£ 100$ for a single bale. In 1956, he set another world record, this time for 'broken wool'. He was also the first to reach $150 \mathrm{~d}$ as an average price per pound for an entire clip. ${ }^{37}$

Table 1: Curran's wool records.

\begin{tabular}{|c|c|c|}
\hline Record & $\begin{array}{l}\text { No. of } \\
\text { times }\end{array}$ & Seasons \\
\hline FCT/ACT record (season) - top price & 25 & $\begin{array}{l}\text { 1933/4, 1935/6, 1937/8-1945/6, } \\
\text { 1947/8-1959/60, 1964/5 }\end{array}$ \\
\hline $\begin{array}{l}\text { Goulburn wool sales - top price } \\
\text { (This was primarily where he sold his clips) }\end{array}$ & 17 & $\begin{array}{l}\text { 1940/1-1945/6, 1947/8-1950/1, } \\
\text { 1952/3-1958/9 }\end{array}$ \\
\hline Sydney wool sales - top price & 2 & $1935 / 5,1938 / 9$ \\
\hline NSW record (at time of sale) - top price & 10 & $\begin{array}{l}\text { 1944/5-1945/6, 1948/9, 1950/1, } \\
\text { 1952/3-1956/7, 1958/9 }\end{array}$ \\
\hline NSW record (season) - top price & 8 & $\begin{array}{l}\text { 1945/6, 1948/9, 1952/3-1956/7, } \\
1958 / 9\end{array}$ \\
\hline Australia record (at time of sale) - top price Merino & 7 & $1944 / 5-1945 / 6,1952 / 3-1956 / 7$ \\
\hline Australia record (season) - top price Merino & 6 & $1945 / 6,1952 / 3-1956 / 7$ \\
\hline Commonwealth record (season) - top price Merino & 6 & 1945/6, 1952/3-1956/7 \\
\hline World record-top price Merino & 1 & $1945 / 6$ \\
\hline World record-top price broken wool & 1 & $1956 / 7$ \\
\hline World record-top price-average per clip & 1 & $1956 / 7$ \\
\hline
\end{tabular}

Source: Compiled from contemporary newspaper reports.

Despite the acclaim and the financial rewards that followed, Curran remained uncomfortable in the face of praise and did his best to deflect attention. In 1954, upon breaking a national record, he told a Canberra Times reporter: 'I would like to give credit to Sir Walter Merriman, because the sheep were founded on Merryville blood over the last 35 years' ${ }^{38}$ Of course, Curran had his share of setbacks. The 1946/7 season was a bad one, as can be seen from Table 1 . His continuing challenge was

36 Canberra Times, 30 October 1945, 3; 5 November 1945, 3; 5 December 1958, 2 (retrospective article noting the $435 \mathrm{~d}$ world record, etc.). The winning bidder was the Emereglido Zegna woollen mill of Trivero, which today manufactures for brands including Gucci, Yves Saint Laurent, Christian Dior and Dunhill.

37 Canberra Times, 22 November 1956, 1; 26 November 1956, 6.

38 Canberra Times, 3 December 1954, 2. 
lack of capital and the need to build up his own infrastructure: specifically, bores and dams, shearing shed, livestock races and holding pens, dog yards, hay sheds and shearers' quarters.

The 'Deasland Ledger' of the 1938-44 seasons shows how crippling the bank interest, rent and leasehold fees were, despite Curran's success. Together, these costs represented just over 33 per cent of the family's operational costs. Their competitors may have faced higher rates as landowners, but nowhere near the Currans' expenses in rent and interest. Thus it is possible that, were it not for the wool boom, Curran would have struggled to service such a high level of debt and would not have been able to have expanded so quickly. ${ }^{39}$

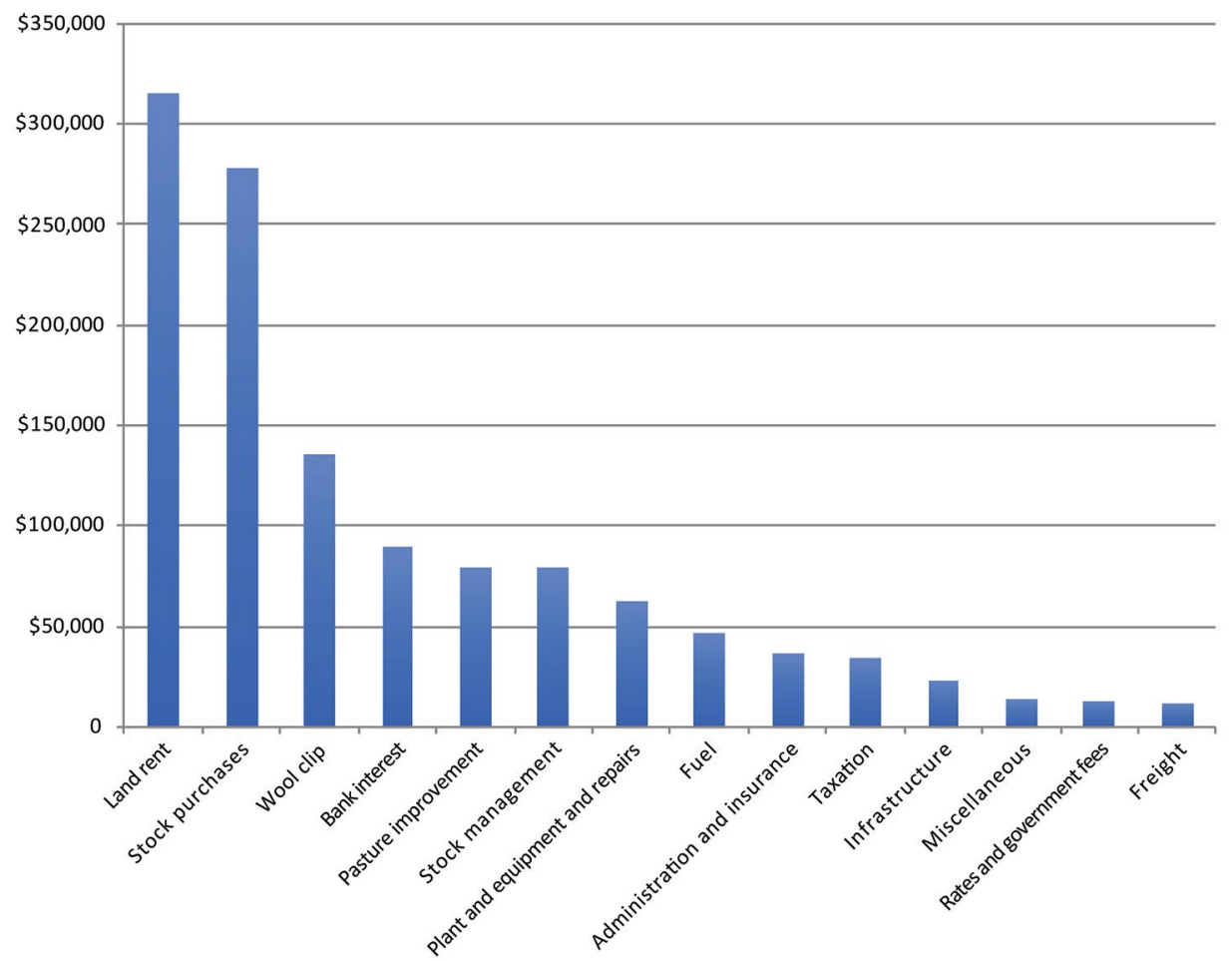

Figure 4: Deasland clip expenditure in modern value (1938-44).

Source: Compiled by James McDonald: Wartime accounts, Curran family, known as the 'Deasland Ledger', 1938-44.

39 Curran was also reported as being financially naive. He was taken advantage of in at least two bad cash loans he had provided to acquaintances and also found himself in taxation trouble after receiving poor accounting advice. Canberra Times, 24 October 1963, 11. 
Curran also faced problems with soil erosion, drought, fire, stock theft, noxious weeds like Scotch thistle, wild dogs, foxes, crows attacking lambs, and plagues of rabbits. ${ }^{40}$ But his successful record as one of Australia's premier wool-growers of the 1944-64 period was based on sound principles of land management. As already mentioned, he deliberately split his holdings so that he could never be burnt out by a single bushfire. He always kept multiple sources of water and feed, was relentless in his battle against pests, and kept his pastures free of burr and weeds so that the wool stayed as clean as possible. Curran meticulously maintained his fences, despite not owning much of his land. He invested heavily in dams and bores and took measures to stabilise the badly eroded gullies leading into Ginninderra Creek. ${ }^{41}$ But he claimed that the main principle was never to overstock and to always plan ahead for bad times, particularly as merino pasture tended to be poor pasture. He was conscious of the need to keep his flocks as active as possible, which had the effect of making the wool finer, and never to let them overgraze. Plenty of feed was always available for the bad times and Curran was usually the leading lucerne grower in the district. There were always at least four haystacks at 'Deasland' in the early days. ${ }^{42}$

As the Australian wool industry peaked in the 1950s and the labour market was as close as it would become to a state of 'full-employment', it grew increasingly hard for wool-growers to attract the best shearers. Some estimates put the wooldependent labour force as high as 20 per cent of employment, nationally. Curran recognised the benefits of a good team of shearers and invested funds to attract them. A bad shearer could devalue a fleece and, worse still, injure a fine ram or ewe. Former Deasland shearers have reported that they would sign on with the Currans in preference to other graziers in the district because the pay was better and the shearers' quarters and food were excellent. ${ }^{43}$

Another key to the success of the 'Deasland clip' was the fact that, despite his limited capital, Curran was prepared to invest generously in technical advice to maintain and improve his bloodline. During the war years he paid double wages to 'Os' Southwell, the best of the district's wool classers, and his own son, Richard, also became an expert wool classer. ${ }^{44}$ The combination of the father's expertise as a grazier and the son's technical knowledge became a significant advantage in the

\footnotetext{
40 Canberra Times, 18 April 1952, 2. Cf. J. C. Garran and L. White, Merinos, Myths and Macarthurs: Australian Graziers and Their Sheep, 1788-1900 (Canberra: Australian National University Press, 1985), 201-10.

41 These measures are reflected in purchases recorded in the 'Deasland Ledger' (1938-44): e.g. tree regeneration stock (18). This document is transcribed in full with commentary in McDonald, Three Henry Currans, 333-401. 42 This may have been something he learnt at an early age from his mother's family, the Gribbles, who were expert reapers and hay-stackers. See Gillespie, Ginninderra, 179-186; McDonald, 'The Chaff Cutters', 11-19.

43 Reported by ex-shearer, Len Coulton, 2006. Cf. the late Lionel Moore, Ginninderra shearer, interviewed in a feature on Curran's career, broadcast on ABC Television's 7.30 Report, 22 March 2013.

44 'Deasland Ledger', 2, 6, 14, 28, 35.
} 
later years. When Richard took over the property after his father's death in 1964, he maintained the success of the Deasland clips and achieved top prices in his own right, until the properties and flocks were dissolved in 1971.

There are still a few Canberra locals, who remember Babe Curran, his energy, generosity and his outstanding record in putting Canberra on the wool-growing map, but few Nicholls, Ngunnawal and Crace residents would know that the finest merinos in Australia once grazed where their children now play. When the subject of the wool industry in Australia arises, what comes to mind for most people are the celebrated achievements of John Macarthur, Walter Merriman and others. ${ }^{45}$ But standing quietly in the background is a Canberran, who had it much harder than his predecessors. He had no easy money behind him. He built his wool empire on a cobbled estate, borrowed capital, the sweat of his brow and a nose for fine wool. Record wool prices were achieved with a flock primarily pastured on the northern outskirts of Canberra. Limestone Plains's sheep pastures are now gone, but whether they were 'ruined' is a matter of personal judgement and one's views of the political impact and success of the Australian Parliament and the city that has grown up around it.

45 See, for example, Charles Trimby Burfitt who devotes 40 per cent of his book to Macarthur: History of the Founding of the Wool Industry of Australia (Sydney: Government Printer, 1913), 4-42. A more balanced account is provided by Garran and White, Merinos, Myths and Macarthurs. For Merriman, see G. P. Walsh, 'Merriman, Sir Walter Thomas (1882-1972)', $A D B$, adb.anu.edu.au/biography/merriman-sir-walter-thomas-7561. 
This text is taken from Australian Journal of Biography and History: No. 2, 2019, published 2019 by ANU Press, The Australian National University, Canberra, Australia.

doi.org/10.22459/AJBH.2019.03 